\title{
Maqashid Syariah and Profitability of Islamic Banks in Indonesia: Quadrant Analysis Measurement Approach
}

\author{
Setyo Tri Wahyudi ${ }^{1, *}$, Kartika Sari², Rihana Sofie Nabella ${ }^{3}$
}

\begin{abstract}
${ }_{1}$ Department of Economics, Faculty of Economics and Business, Universitas Brawijaya, Indonesia ${ }^{2}$ Department of Economics, Faculty of Economics and Business, Universitas Brawijaya, Indonesia ${ }^{3}$ Department of Economics, Faculty of Economics and Business, Universitas Brawijaya, Indonesia *Corresponding author. Email: setyo.tw@ub.ac.id
\end{abstract}

\begin{abstract}
Islamic banks are required to comply with sharia principles in conducting their business. One of the principles of sharia is maqashid sharia. Maqashid sharia carries social values such as the value of education, justice, and economic prosperity. Nowadays, apart from pursuing profit, Islamic banks should also comply with maqashid sharia principles. This study aims to determine the social role of Islamic banks in addition to the business objectives of Islamic banks and achieving profitability in 4 Islamic banks. They are Bank Muamalat Indonesia (BMI), BRI Syariah (BRIS), BNI Syariah (BNIS), and Bank Syariah Mandiri (BSM). The method used to determine maqashid sharia measures the maqashid sharia index (MSI). At the same time, profitability is known by using the comparative performance index method in four Islamic banks spread across Indonesia in 2019-2020 quarter. To determine the achievement of maqashid sharia and profitability, a quadrant analysis measurement (QAM) was performed. The results showed that only BMI belonging to the ULQ quadrant (not good SMI and good profit) and BRIS, BNIS, and BSM entered the LLQ quadrant (not good maqashid sharia, not good profit) on a quarterly average in the research year. Therefore, the Indonesian central bank can provide incentives, especially for Islamic banks in Indonesia that are not good at sharia maqashid, and urge Islamic banks to include maqashid sharia principles in the vision and mission of Islamic banks. Indonesia's central bank can also encourage Islamic banks that are also not doing well in achieving profits by switching to digital technology to increase efficiency, continue to innovate while increasing the convenience of bank services.
\end{abstract}

Keywords: maqashid shariah, profitability, sharia banking, sharia principles

\section{INTRODUCTION}

The existence of Islamic banks cannot be denied in the banking industry. Many conventional banks are starting to be interested in establishing a sharia business unit due to the significant potential profit generated when a bank can meet customer needs preferences following sharia principles in the maqashid sharia concept. Islamic banks are required to comply with sharia principles in running their business. The sharia principles include the prohibition of transactions involving interest or usury, gharar (risky sales), and maysir (gambling).

Today, in addition to pursuing profit (business goals), Islamic banks should also adjust their business to the initial purpose of forming Islamic banks (maqashid sharia). Conceptually, maqashid shariah carries social values such as the value of economic welfare, justice, fair income distribution, and social welfare (Lahsasna and Sulaiman, 2010). the. Maqashid sharia carries social values such as the value of education, economic welfare (zakat, real investment), and justice (partnership).
These goals have to be fulfilled in order to make the Islamic banks known as banks that pursue profit and run operations following Islamic maqashid. One of the wellknown Islamic banking operations based on maqashid sharia is the partnership system with mudarabah and musyarakah contracts (the value of justice) because it is a profit-loss sharing system and is not involved in transactions that violate sharia principles (usury, maysir, and gharar). In a partnership-based contract, the customer/bank acts as a shahibul maal (fund owner) or mudharib (fund manager in a partnership system (Chazi \& Syed, 2010). The bank and customer relations become business partners so that losses are shared and profits are fairly distributed.

In addition, there is a stigma that Islamic banks are the same as conventional banks. One of the reasons is that Islamic banks still refer to the same reference used by conventional banks in determining margins and ratios. Karim (2008) suggests that some Islamic banks refer to the London Interbank Offered Rate (LIBOR). Several Islamic banks in Kuwait and Qatar also use conventional inter-bank rate references in setting margins/ratios (Smaoui and Nechi, 2018). Therefore, Islamic banks can implement the allocation 
of zakat funds (which is in the maqashid sharia concept) as a cleaner of wealth and reduce inequality.

Departing from the theoretical gap and the stigma that Islamic banks and conventional banks are the same in operations, the study of business objectives and Islamic maqashid becomes essential. They were considering that Islamic banks are subject to sharia principles in carrying out their functions. In addition, Islamic banks can be known as banks that are profit-oriented (business goals) but carry social values in the maqashid sharia concept. Therefore, the formulation of the problem is to analyze the maqashid sharia and the profitability of Islamic banks in Indonesia.

\section{LITERATURE REVIEW}

Research on the maqashid sharia index has been carried out quite a lot, including Ascarya et al. (2016) the objectives of sharia Islamic banks in Indonesia and other Islamic countries using the Simple Additive Weighting (SAW) and Bedoui Pentagon methods. The results show that the maqashid sharia index value is relatively low, if ranked the best banks for achieving maqashid sharia are BNI Syariah, Bank Syariah Mandiri, BRI Syariah, Mizan Bank of Pakistan, Bank Permata Syariah, and Bank Muamalat Indonesia of Indonesia, followed by Al -Rajhi Bank, Kuwait Finance House, Qatar Islamic Bank, Islamic Bank Malaysia Berhad, and Dubai Islamic Bank.

Rusydiana et al. (2017) aim to examine the maslahah that exists in the maqashid sharia concept associated with efficiency in a framework called the Maslahah Efficiency Quadrant (MEQ) for 2011-2014. Because both Bank Muamalat Indonesia (BMI) and Bank Panin Syariah are in the first quadrant, the results show that they are both good. In the second quadrant, Bank Syariah Mandiri (BSM), Maybank Syariah, and Bank Syariah Bukopin are all considered good.; Bank Rakyat Indonesia Syariah (BRI) and BCA Syariah are fair, positioned in the third quadrant; and Bank Mega Syariah, Victoria Syariah, Bank Negara Indonesia Syariah (BNI), and Bank Jabar Banten Syariah (BJB) are poor in the fourth quadrant. This encourages Islamic banks that are at a low level of the Islamic maqashid index. In addition, it is essential to have efficiency to achieve maslahah.

Fadillah, Firmansyah \& Wahid (2018) researched the profitability and maqashid Syariah index (MSI) with the Syariah maqashid index (MSI) model compared to its financial performance. The quadrant analysis with quadrant analysis measures (QAM) method was applied. The results revealed that Panin Syariah Bank was the best performing Islamic bank, while Mega Syariah Bank had the best financial performance. Bank Muamalat, BRI Syariah, Panin Syariah, Bank Syariah Bukopin, and BCA Syariah are among the banks have good maqoshid and financial performance. It can be said; no bank has good economic performance and the achievement of maqashid sharia.

\section{METHODS}

\subsection{Research Approach and Research Object}

This research is descriptive quantitative research. The object of this research is Islamic banks in Indonesia. The research object is Muamalat Bank, BRI Syariah, BNI Syariah and Mandiri. Researchers use the purposive sampling method in selecting research objects with specific considerations; among others, these banks have the most significant business scale (total assets) because banks with large business scales can impact small banks. For example, when a large bank goes bankrupt, it will affect other smaller banks.

\subsection{Analysis Method}

\subsubsection{Measurement and Model of Islamic Bank Maqashid Index}

The method of measuring the achievement of Islamic maqashid in this study used the maqashid sharia index (SMI) based on research conducted by Mohammed \& Omar (2008), Mohammed, Mutafa Omar \& Taib (2009) have developed Islamic banking performance based on the theory of Maqashid Syariah, namely the Performance Measure based on Maqashid Syariah (PMMS). This model consists of several performance dimensions. The performance measurement reflects the responsibilities and obligations of Islamic banks. The following is the operation of the Performance Measure based on Maqashid Syariah (PMMS) model as follows:

Table 1. Performance Measure based on Maqashid Syariah Model

\begin{tabular}{|c|c|c|c|}
\hline Goal & Dimension & ELement & $\begin{array}{c}\text { Performance } \\
\text { Ratio }\end{array}$ \\
\hline \multirow[t]{4}{*}{$\begin{array}{l}\text { Tahdib Al Fard/ } \\
\text { Educating }\end{array}$} & $\begin{array}{l}\text { D1. } \\
\text { Knowledge }\end{array}$ & $\begin{array}{l}\text { E1 } \\
\text { Education } \\
\text { Grant }\end{array}$ & $\begin{array}{l}\text { R1. Education } \\
\text { Grant/ Total } \\
\text { Expense }\end{array}$ \\
\hline & \multirow[t]{2}{*}{ D2. Skill } & $\begin{array}{l}\text { E2. } \\
\text { Research }\end{array}$ & $\begin{array}{l}\text { R2. Research } \\
\text { Expense/ } \\
\text { Total Expense }\end{array}$ \\
\hline & & $\begin{array}{l}\text { E3. } \\
\text { Training }\end{array}$ & $\begin{array}{l}\text { R3. Training } \\
\text { Expense/ } \\
\text { Total expense }\end{array}$ \\
\hline & $\begin{array}{l}\text { D3. } \\
\text { Awareness }\end{array}$ & $\begin{array}{l}\text { E4. } \\
\text { Publicity }\end{array}$ & $\begin{array}{l}\text { R4. } \\
\text { Publicity } \\
\text { Expense/ } \\
\text { Total Expense }\end{array}$ \\
\hline \multirow[t]{3}{*}{$\begin{array}{l}\text { Iqamah Al Adll } \\
\text { Justice }\end{array}$} & \multirow[t]{2}{*}{ D5. Fair } & $\begin{array}{l}\text { E5. } \\
\text { Fair } \\
\text { Returns }\end{array}$ & $\begin{array}{l}\text { R5. } \\
\text { Profit } \\
\text { Equalization } \\
\text { Reserves/Net } \\
\text { Investment } \\
\text { Income }\end{array}$ \\
\hline & & $\begin{array}{l}\text { E6. } \\
\text { Functional } \\
\text { Distributio } \\
\mathrm{n}\end{array}$ & $\begin{array}{l}\text { R6. } \\
\text { Mudarabah } \\
\text { Musyarakah } \\
\text { Modes/ } \\
\text { total financing }\end{array}$ \\
\hline & $\begin{array}{l}\text { D6. } \\
\text { Elimination of } \\
\text { Negative } \\
\text { Elements That }\end{array}$ & $\begin{array}{l}\text { E7. } \\
\text { Interest } \\
\text { Free } \\
\text { product }\end{array}$ & $\begin{array}{l}\text { R7. Interest } \\
\text { Free Product/ } \\
\text { Total Income }\end{array}$ \\
\hline
\end{tabular}




\begin{tabular}{|l|l|l|l|}
\hline \multicolumn{1}{|c|}{ Goal } & \multicolumn{1}{|c|}{ Dimension } & ELement & $\begin{array}{l}\text { Performance } \\
\text { Ratio }\end{array}$ \\
\hline & $\begin{array}{l}\text { Breed } \\
\text { Injustices }\end{array}$ & & \\
\hline $\begin{array}{l}\text { Jalb } A l \\
\text { Maslahah }\end{array}$ & $\begin{array}{l}\text { D7. } \\
\text { Profitability of } \\
\text { Bank }\end{array}$ & $\begin{array}{l}\text { E7. Profit } \\
\text { Ratio }\end{array}$ & $\begin{array}{l}\text { E7. Net } \\
\text { Income/Total } \\
\text { asset }\end{array}$ \\
\hline & $\begin{array}{l}\text { D8. } \\
\text { Redistribution } \\
\text { Income \& } \\
\text { Wealth }\end{array}$ & $\begin{array}{l}\text { E8. } \\
\text { Personal } \\
\text { lncome } \\
\text { paid/Net } \\
\text { Income }\end{array}$ \\
\hline & $\begin{array}{l}\text { D9. } \\
\text { Investment inector }\end{array}$ & $\begin{array}{l}\text { E9. } \\
\text { Investment } \\
\text { Ratio in } \\
\text { Real } \\
\text { Income }\end{array}$ & $\begin{array}{l}\text { R9. } \\
\text { Investment in } \\
\text { Riel Economic } \\
\text { Sectors/total } \\
\text { Investment }\end{array}$ \\
\hline
\end{tabular}

Source (Omar,2008)

\subsubsection{Weighting of the Maqashid Sharia Index Measurement Model}

To get the best results from the above measurements, verification of the model and weighting of each sharia objective, dimension, and element was carried out through interviews with 16 sharia experts in Asia and the Middle East. The weighting is based on the results of research from Mohammed \& Omar (2008), as shown in the following table:

Table 2. Average Weight of Islamic Maqashid Objectives and Measurement Elements

\begin{tabular}{|c|c|c|c|}
\hline Goal & $\begin{array}{l}\text { Average } \\
\text { Weight }\end{array}$ & Element & $\begin{array}{l}\text { Average } \\
\text { Weight }\end{array}$ \\
\hline \multirow{4}{*}{$\begin{array}{l}\text { 1. Tahzib al- } \\
\text { Fard } \\
\text { (Educating } \\
\text { Individual) }\end{array}$} & \multirow[t]{4}{*}{0,3} & $\begin{array}{l}\text { E1. Education } \\
\text { Grant }\end{array}$ & 0,24 \\
\hline & & E2. Research & 0,27 \\
\hline & & E3. Training & 0,26 \\
\hline & & E4. Publicity & 0,23 \\
\hline \multirow{4}{*}{$\begin{array}{l}\text { 2. Iqamah al- } \\
\text { Adl } \\
\text { (Establishing } \\
\text { Justice) }\end{array}$} & \multirow[t]{4}{*}{0,41} & $\begin{array}{l}\text { E5. Fair } \\
\text { returns }\end{array}$ & 0,30 \\
\hline & & $\begin{array}{l}\text { E6. } \\
\text { Functional } \\
\text { Distribution }\end{array}$ & 0,32 \\
\hline & & $\begin{array}{l}\text { E7. Interest } \\
\text { free Product }\end{array}$ & 0,38 \\
\hline & & Total & 1 \\
\hline \multirow{4}{*}{$\begin{array}{l}\text { Jalb al- } \\
\text { Maslaha } \\
\text { (Public } \\
\text { Interest) }\end{array}$} & \multirow[t]{4}{*}{0,29} & $\begin{array}{l}\text { E8. Profit } \\
\text { ratios }\end{array}$ & 0,33 \\
\hline & & $\begin{array}{l}\text { E9. Personal } \\
\text { Income }\end{array}$ & 0,30 \\
\hline & & $\begin{array}{l}\text { E10. } \\
\text { Investment } \\
\text { Ratios in Real } \\
\text { Sector } \\
\end{array}$ & 0,37 \\
\hline & & Total & 1 \\
\hline
\end{tabular}

Source: Omar, 2008.

\subsubsection{Measurement of profitability index with Comparative Performance Index (CPI)}

In measuring the profitability of Islamic banks in this study used the average of Return on Assets (ROA), Return on Equity (ROE), and Net Profit Margin (NPM) Parisi \& Aam (2016) and Rozzani \& Rohman (2013), the following formula from ROA, ROE, NPM:

$$
\begin{aligned}
& \mathrm{ROA}=\frac{\text { profit } \text { before } \text { tax }}{\text { Asset total }} \\
& \mathrm{ROE}=\frac{\text { profit before } \text { tax }}{\text { Capital total }} \\
& \mathrm{ROE}=\frac{\text { profit after } \text { tax }}{\text { operating income }}
\end{aligned}
$$

Next, the ranking of the profitability index is carried out. This can be done using the Comparative Performance Index (CPI) method. Comparative Performance Index (CPI) is one method for decision-making based on the performance index. CPI is a composite index that is used to determine the assessment or ranking of various alternatives.

\subsubsection{Quadrant Analysis Measurement}

After obtaining the results of the profitability index and the Islamic maqashid index, the results will be inputted in the form of a Cartesian diagram. The first step in this analysis is to calculate the value or average score of the profitability index and the sharia maqashid index. Second, make a plot based on the average value/score of each aspect into a Cartesian diagram where the profitability index as the vertical axis with the symbol (y) and the sharia maqashid index as the horizontal axis with the character ( $\mathrm{x}$ ) can be simplified using the following formula:

$\mathrm{x}=\sum \mathrm{xi} / \mathrm{n}$

$\mathrm{y}=\sum \mathrm{yi} / \mathrm{n}$

\section{Information:}

$\mathrm{x}=$ average score of Islamic bank profitability index

$\mathrm{y}=$ average score of sharia maqashid index

$\mathrm{xi}=$ total score of each level of profitability of the entire sample of Islamic banks

$\mathrm{yi}=$ total score for each level of the Islamic maqashid index of all Islamic bank samples

$\mathrm{n}=$ number of Samples

\section{RESULTS AND DISCUSSIONS}

This study aims to measure the performance of Islamic banking in Indonesia with up to 4 Islamic banks using the maqashid shariah index. The overall performance of Islamic banking in Indonesia can be seen in Table 4. Based on these results, it is known that the Islamic bank with maqashid sharia performance in Indonesia is Bank Rakyat Indonesia Syariah (BRIS) in the first quarter of 2020 with a maqashid shariah index value of $23.9 \%$.

Then, followed by Bank Negara Indonesia Syariah (BNIS) in the third quarter of 2019 with a maqashid shariah index value of $22.7 \%$. The third is Bank Syariah Mandiri (BSM) in the first quarter of 2019 with a maqashid shariah index value of $21.6 \%$. Meanwhile, Bank Muamalat, in this result, ranks fourth in terms of performance. That is, two banks are good at maqashid sharia or achieving sharia goals from the indicators of education, justice, and problems. This study is in line with Parisi \& Aam. (2016) that BSM and BNIS banks are classified as banks with a high Islamic maqashid value. 
Next is the Comparative Performance Index (CPI) value based on the average profitability ratio, namely ROA, ROE, and PER. This index aims to see the performance of Islamic banks. Based on the results of the CPI calculations presented in Table 5, it was found that the Islamic Bank with the highest CPI was Bank Muamalat in the first quarter of 2020 at 245.22 .

In second place is Bank Syariah Mandiri (BSM) with a CPI value of 108.36. However, the CPI value is still relatively low. These results are supported by Kuppusamy, Saleh, \& Samudhram (2010) that the value of the Comparative Profitability Index $>$ the average alternative value has high profitability. This shows the excellent achievement of banking performance.

Table 3. Comparative Performance Index (CPI)

\section{By Quarter}

\begin{tabular}{|l|c|c|c|c|}
\hline \multicolumn{1}{|c|}{ Bank } & $\begin{array}{c}\text { ROA } \\
* 0,33\end{array}$ & $\begin{array}{c}\text { ROE } \\
* 0,33\end{array}$ & $\begin{array}{c}\text { NPM } \\
*, 33\end{array}$ & CPI \\
\hline MANDIRI TRI 12019 & 33,00 & 33,00 & 33,00 & 99,00 \\
\hline MANDIRI TRI II 2019 & 37,22 & 36,72 & 20,45 & 94,39 \\
\hline MANDIRI TRI III 2019 & 38,95 & 38,14 & 19,88 & 96,97 \\
\hline MANDIRI TRI IV 2019 & 41,93 & 41,02 & 25,40 & 108,36 \\
\hline MANDIRI TRI 2020 & 31,29 & 30,26 & 31,11 & 92,67 \\
\hline MANDIRI TRII 2020 & 31,47 & 31,57 & 32,18 & 95,22 \\
\hline MANDIRI TRI III 2020 & 32,41 & 32,55 & 32,77 & 97,72 \\
\hline MANDIRI TRI IV 2020 & 33,00 & 33,00 & 33,00 & 99,00 \\
\hline MUAMALAT TRI 2019 & 33,00 & 33,00 & 54,77 & 120,77 \\
\hline MUAMALAT TRI II 2019 & 33,00 & 35,64 & 58,81 & 127,45 \\
\hline MUAMALAT TRI III 2019 & 33,00 & 34,32 & 33,00 & 100,32 \\
\hline MUAMALAT TRI IV 2019 & 82,50 & 59,40 & 100,25 & 242,15 \\
\hline MUAMALAT TRI 1 2020 & 33,00 & 34,14 & 178,38 & 245,52 \\
\hline MUAMALAT TRI II 2020 & 33,00 & 34,14 & 47,21 & 114,35 \\
\hline MUAMALAT TRI III 2020 & 33,00 & 33,00 & 49,21 & 115,21 \\
\hline MUAMALAT TRI IV 2020 & 33,00 & 33,00 & 33,00 & 99,00 \\
\hline BRIS TRI I 2019 & 23,79 & 19,62 & 18,13 & 61,54 \\
\hline BRIS TRI II 2019 & 31,97 & 33,00 & 31,50 & 96,47 \\
\hline BRIS TRI III 2019 & 31,97 & 31,14 & 31,12 & 94,23 \\
\hline BRIS TRI IV 2019 & 33,00 & 31,74 & 33,00 & 97,74 \\
\hline BRIS TRI I 2020 & 26,73 & 42,69 & 24,09 & 93,51 \\
\hline BRIS TRI II 2020 & 29,70 & 33,00 & 31,71 & 94,41 \\
\hline BRIS TRI III 2020 & 31,82 & 3,52 & 29,84 & 65,18 \\
\hline BRIS TRI IV 2020 & 33,00 & 34,08 & 33,00 & 100,08 \\
\hline BNIS TRI I 2019 & 33,00 & 33,00 & 33,00 & 99,00 \\
\hline BNIS TRI II 2019 & 27,81 & 28,55 & 28,64 & 85,00 \\
\hline BNIS TRI III 2019 & 28,68 & 29,78 & 29,68 & 88,14 \\
\hline BNIS TRI IV 2019 & 30,10 & 30,83 & 30,65 & 91,58 \\
\hline BNIS TRI I 2020 & 19,59 & 18,33 & 20,05 & 57,97 \\
\hline BNIS TRI II 2020 & 30,27 & 30,30 & 29,14 & 89,70 \\
\hline BNIS TRI III 2020 & 32,04 & 31,85 & 31,21 & 95,10 \\
\hline & Average aIterIVtiv CPI & & \\
\hline
\end{tabular}

$*$ Average alternative CPI quarterly for all banks $=104.8$

Source: (researcher, 2020)

Sinamora (2010:29) mentions the benefits obtained from holding education and training (Diklat), namely: a) Improving the quality and quantity of productivity b) Reducing the learning time needed by employees to achieve the specified performance standards c) Creating attitudes, loyalty, and more profitable cooperation d) Meet the requirements of human resource planning e) Reduce the number and cost of work accidents f) Assist employees in their improvement and development.
In addition, Bank Muamalat also excels in terms of the allocation of promotional funds. The highest percentage of funds for promotions, especially in the third quarter of 2019, was $6.91 \%$. This means that the bank prioritizes forming a bank brand image to attract customers through various commercial means. This method can be done by utilizing mass media, television advertisements about bank products to increase public awareness of bank products. Mahajar, Yunus (2011) argues that advertising is essential to create brand awareness, increase interest in brands, and influence product buying behavior.

Meanwhile, in 2020, the bank with the largest allocation of funds for educational purposes is Bank Nasional Indonesia Syariah (BNIS). The training held by BNIS includes in-house training, which is part of the training for new employees and in collaboration with the Human Resources Division. Especially for the Risk Management Division employees, competency improvement is routinely carried out through workshops related to risk management conducted annually. BNI Syariah strives to foster a risk culture.

Pribadi (2013) added that education and training for employees are vital to be applied in an agency. With education and training, employees are expected to work more effectively and efficiently, primarily to deal with the changes that occur. So, companies that want to grow must pay great attention to education and funding for their employees.

As seen in the table above, the bank that allocated the most funds for the equity indicator or the second Performance Indicator (IKT2) was the BRIS bank at 0.130 in 2019 and BSM at 0.129 in 2020. This is the superiority of this bank in the profit equalization ratio (PER). It can be interpreted, Muamalat bank can provide optimal profit to shareholders. Ramli, Shahimi, Ismail, and Ghafar (2012) suggest that PER is a reserve formed from allocating investment profits to be distributed to shareholders, which stabilizes periodic profit payments. Based on AAOIFI and IFSB, PER ensures that investors' returns are guaranteed and can increase owner's equity (Salman and Htay \& Salman (2013).

In addition, the allocation of BRIS and Muamalat banks for profit-sharing/partnership-based financing (mudarabah and musyarakah) is also higher than other banks. As an illustration, the highest percentage of each bank in a partnership contract is $90 \%$ and $41 \%$ in the first quarter of 2019. This is in line with the maqashid sharia theory, which states that the sharia banking system is based on partnership (the value of justice in sharia maqashid). Filippo (2013) says that the benefits of Islamic banks using a partnership system or profit-sharing in their financing are the partnership or profit-sharing system being community-oriented, businessfriendly, emphasizing productivity, and expanding financial services.

Some examples of violations of justice are not explicitly showing the procedures in the musharaka contract for their 
clients on the official website, mortgaging the customer's property on behalf of the bank. Mahmood and Naim (2015) describe things that do not carry justice, namely Jordan's banks delaying profit sharing. Profit delays are carried out until profits are equal to capital so that customers take a long time to get profit sharing. Next, it does not explicitly show the procedures in the musharaka contract for its clients on its official website, mortgaging the customer's property on behalf of the bank.

\section{CONCLUSIONS AND SUGESTIONS}

The results showed that only BMI classified as good profitability but not good at achieving maqashid sharia. Meanwhile, BRIS, BNIS and BSM achieved poor sharia maqashid and their profitability was also not good on an average quarterly basis in the study year. Profit achievement is not good because the value of the comparative performance index is less than the average alternative value $(104,8)$. Meanwhile, the achievement of maqashid sharia is not good if the maqashid sharia index value is less than 0.2 .

The results of this study are not in accordance with the maqashid sharia theory which states that maqashid sharia can encourage human welfare/maslahah. If a business entity is based on maqashid sharia, then the business entity fulfills the public interest (Chapra, 2011). However, in this study the achievement of maqashid shariah is still not good. Furthermore, this result is in-line with the study of Rusydiana et al. (2017), Fadillah, Firmansyah \& Wahid (2018) stating that there are still many of Islamic banks that are not good at achieving maqashid sharia.

For the suggestions, the Indonesian central bank can provide incentives such as the ease of obtaining capital loans, especially for Islamic banks in Indonesia that are already good at maqashid sharia. This can encourage other Islamic banks to increase the value of maqashid sharia. In addition, Islamic banks can include the principles of maqashid sharia in the vision and mission of Islamic banks.

The Indonesian central bank can also appeal to Islamic banks that are also not good at making profits to take advantage of digital technology to improve bank efficiency, and take advantage of digital technology to attract new customers and increase customer satisfaction.

\section{REFERENCES}

[1] Afrinaldi. (2013). Analisa Kinerja Perbankan Syariah Indonesia Ditinjau dari Maqosid Syariah: Pendekatan Syariah Maqosid Indeks (SMI) dan Profitabilitas Bank Syariah. Islamic Economic \& Finance (IEF) Universitas Trisakti.
[2] Ali, \& Hatta. (2014). Zakat As a Poverty Reduction Mechanism Among the Muslim Community: Case Study of Bangladesh, Malaysia, And Indonesia. Asian Social Work and Policy Review, $\quad 8(1), 59-70$.

[3] Antonio. Sanrego, and Taufiq. (2012). An Analysis of Islamic Banking Performance: Maqashid Index Implementation in Indonesia and Jordania. IIUM Institute of Islamic Banking and Finance. Journal of Islamic Finance, 1(1).

[4] Ascarya et al. (2016). Measuring The Islamicity of Islamic Bank In Indonesia And Other Countries Based On Shari'ah Objectives. Islamic Conference on Islamic Economics and Finance", organized by International Islamic University Malaysia (IIUM), Islamic Research and Training Institute - Islamic Development Bank (IRTI-IDB) and International Association of Islamic Economics (IAIE),

[5] Chapra. (2011). Islam Dalam Pembangunan Ekonomi: Menurut Maqashid Syariah. Solo: Al Hambra.

[6] Chazi \& Syed. (2010). Risk exposure during the global financial crisis: the case of Islamic banks. International Journal Islamic Middle Eastern Finance Management, 321-333.

[7] Fadillah, Firmansyah, \& Wahid. (2018). Analisis Kinerja Bank Syariah Dengan Maqashid Syariah Index (Msi) Dan Profitabilitas . Jurnal Akuntansi , 19.

[8] Filippo (2013). Islamic Finance in Europe. European Central Bank, 2013 Occasional Paper Series No 146 / June 2013.

[9] Gul, Sherish. Irshad. Faiza. Zaman. Khalid. (2011). Factors Affecting Bank Profitability in Pakistan. Romanian Economic Journal, (January), 6187.

[10] Kabajeh, Majed, Al-Nu'aimat, Said. \& Dahmash, (2012). The Relationship between ROA, ROE and ROI Ratios with Jordanian Insurance Public Companies Market Share Prices. International Journal of Humanities and Social Science, 2(11), 115-120.

[11] Karim. (2008). Bank Islam (Analisis Fiqih dan Keuangan), Jakarta: PT Raja Grafindo.

[12] Kuppusamy, Saleh, \& Samudhram, (2010). Measurement of Islamic Banks Performance Using a Shari'Ah Conformity and Profitability Model. Review of Islamic Economics., 13(2), 35-48.

[13] Lahsasna, \& Sulaiman. (2010). Realizing Maqashid al Shariah in Islamic Financial Planning. Paper presented at the 4th Islamic banking, accounting and finance seminar (IBAF 2010). 
[14] Magda. (2011). Zakah from Salary and EPF: Issues and Challenges. International Journal of Business and Social Science, vol 2, no 1.

[15] Mahajar, Yunus (2011). The Effectiveness of The Promotional Tools in Creating Awareness Toward Customers of Islamic Banking in Malaysia. Management, 9(1).

[16] Mahmood, \& Naim. (2015). Regulatory Framework and Practice of Musharakah Mutanaqisahin Islamic Banks of Jordan. Journal of Islamic Economics, Banking and Finance, 4(11). 115126.

[17] Mia Angelina Setiawan. (2015). Peranan Investasi Sektor Riil Untuk Meningkatkan Perekonomian Di Sumatera Barat Dalam Menghadapi Masyarakat Ekonomi ASEAN.Seminar Nasional Ekonomi Manajemen dan Akuntansi (Snema) Fakultas Ekonomi Universitas Negeri Padang Snema-2015.

[18] Mohammed \& Omar. (2008). The Performance Measures of Islamic Banking Based on the Maqashid Framework. Paper of IIUM International Accounting Conference.

[19] Mohammed, Mutafa Omar. dan Taib. (2009). Testing The Performance Measured Based on Maqashid alSharia (PMMS) Model on 24 Selected Islamic and Conventional Banks. Malaysia: IIUM.

[20] Parisi, \& Aam. (2016). The Measurement of Islamic Bank Performance: A Study Using Maqashid Index and Profitability. Global Review of Islamic Economics and Business, vol 4(1).

[21] Pribadi, A. T. (2013). Pengaruh Pendidikan dan Pelatihan terhadap Kemampuan dan Kinerja Karyawan (Studi Pada Karyawan PDAM Kota Malang. Jurnal Administrasi Bisnis UB, Vol. 3 (1), 2013.

[22] Ramli, Shahimi, \& Ismail, Ghafar. (2012). Do Malaysian Islamic Banks Manage Earnings through Profit Equalization Reserve? Proceeding of the 14th MFA Conference 2012, 20, 1-20.

[23] Rozzani, \& Rohman. (2013). Camels and Performance Evaluation of Banks in Malaysia:Conventional vs Islamic . Journal of Islamic Finance and Business Research, vol 2(1),3645 .

[24] Rusydiana, et al (2018). Measuring The Performance of Islamic Banking in Indonesia: An Application of Maslahahefficiency Quadrant (Meq). Journal of Islamic Monetary Economics and Finance, vol 3,

[25] Salman dan Htay (2013). Practice of Profit Equalization Reserve and Investment Risk Reserve by Islamic Banks. International Journal of Research in Social Sciences, Vol. 2(2).
[26] Sinamora, Henry. 2010. Manajemen Sumber Daya Manusia. Edisi Tiga. Penerbit:STIE YKPN Yogyakarta.

[27] Smaoui, \& Nechi. (2018). Interbank Offered Rates in Islamic Countries: Is the Islamic Benchmark Different from Conventional Benchmarks? The Quarterly Review of Economics and Finance.

[28] Syauqi. (2016). Ekonomi Pembangunan Syariah. Jakarta: PT Raja Grafindo Persada.

[29] Taib. (2010). Developing Islamic Bank Performance Measure Based on Maqashid Al- Shariah Framework. Journal of Islamic Monetary Economics and Financial.

[30] Wahyi \& Dwita (2020). Dampak Distribusi Zakat Dalam Mengurangi Kemiskinan Berdasarkan Model Cibest (Studi Kasus Di Baznas Kota Pekanbaru), Jurnal Tabarru: Islamic Banking and Finance, 3(2). 